\title{
The Fascinating History of Bergamot (Citrus Bergamia Risso \& Poiteau), the Exclusive Essence of Calabria: A Review
}

\author{
Gina Maruca ${ }^{1}$, Gaetano Laghetti ${ }^{1}$, Rocco Mafrica ${ }^{2}$, Domenico Turiano ${ }^{3}$ and Karl Hammer ${ }^{4}$ \\ 1. Institute of Bioscience and Bioresouces, National Council of Research, Bari 70126, Italy \\ 2. Institute of Agronomy, Department of Agrarian, Mediterranean University of Reggio Calabria, Reggio Calabria 89122, Italy \\ 3. Sperimental Demonstrative Centre of the Straits of Messina, Regional Administration for the Development of the Calabrian \\ Agriculture, Reggio Calabria 89100, Italy \\ 4. Former Agrobiodiversity, University of Kassel, Witzenhausen D-37213, Germany
}

\begin{abstract}
The bergamot (Citrus bergamia Risso et Poiteau), a citrus fruit growing almost exclusively in the South Italy, is considered the "prince of citrus" for its storical role in the perfume industry due to its essential oil, a product in great demand of a pleasant and refreshing scent. Recently, analgesic, anxiolytic, neuroprotective consistent effects have been ascribed to bergamot essential oil when it is used in aromatherapy, for the relief of pain and symptoms associated with stress-induced anxiety and depression. Moreover, today, bergamot fruit due to a considerable abundance and variety of nutraceutical compounds which are present in its juice, is becoming increasingly important also in the food, pharmaceutical and confectionery industries. In this review, it is discussed that the literature on C. bergamia, focusing on the several studies performed with the experimental data, and recently accumulated, may form the rational basis for further development.
\end{abstract}

Key words: Bergamot (Citrus bergamia Risso \& Poiteau), essential oil.

\section{Introduction}

\subsection{Origins}

The bergamot (Citrus bergamia Risso \& Poit., syn.: Citrus aurantium L. subsp. bergamia (Risso et Poit.) Wight et Arn. Engl.) is an aromatic citrus fruit resembling in size, an orange with a yellow color, similar to a lemon. It belongs to the Rutaceae family of the Citrus genus and it was mentioned by Ferrari, for the first time, in 1646, in his monography Hesperides sive de malorum aureorum cultura et usu, as an "aurantium stellatum et roseum"; only later, in 1708, it was described in detail by Volkamer, in his Nurnbergische Hesperides, as "gloria limonum fructus inter omnes nobilissimus" who reported the

Corresponding author: Gina Maruca, researcher, main research field: ethnobotany. distinctive and desiderable characteristics of its essential oil [1]. Bergamot has been known, in the Mediterranean, for several centuries, as the distinctive and desiderable characteristics of its oil having been recognized, as early as 1750 . Until now, both the centre of origin and the significance of its name are unknown. Almost all citrus species, are believed to beoriginated from several thousand years ago, in the tropical and subtropical regions of Southeast Asia and then they spread globally, following ancient land and sea routes [2]. The lineages that gave rise to most modern cultivated varieties, have been lost in undocumented antiquity and their identities remain controversial [3, 4]. It is not an easy task to trace back the path which led to their worldwide diffusion principally, because Citrus has a long history of cultivation (more than 4,000 years) and a wide dispersion [5]. Presumably, C. bergamia originated as 
seedling, in Southern Italy [6]. It is an hybrid of $C$. aurantium x $C$. medica [7] whose the sour orange $(C$. aurantium L.) is the maternal parent, and citron (C. medica L.) is the paternal one [8]. The origin of the name and its significance is a matter of conjecture; there is general agreement, that it derived from Turkish word "beg-a-mudi" which means "Pears of the Prince", due to its certain resemblance to the bergamot pear, represented in a painting of B. Bimbi of $1715[9,10]$. However, since the beginning of the sixteenth century, the bergamot was known only, as ornamental plant that decked the gardens of the aristocratic Italian families. Later, due to a Sicilian gentleman, Francis Procopius who around 1686, introduced in France, the "bergamot water", a very fine essence obtained from the peel of bergamot fruit, it became the more precious component of the most charming perfumes. Almost at the same time, in the Cologne town, another Italian emigrant, Paolo Feminis, developed the "cologne water" (eau de cologne), perhaps the most widely used toilet water that was commercialized, in the same town, by his son-in-law, Gian Maria Farina. Its manufacture dates back to 1709 [11]. The essence was utilized with success also, in beauty and toilette treatment and quickly, its European demand grew very much. So, in 1750, near Reggio Calabria town, in the Giunchi Feudal Estate, the first known bergamot orchard, was planted by the owner Nicola Parisi. Later, the $C$. bergamia growing increased and expanding rapidly along the Straits of Messina area $[12,70]$.

\subsection{Essence History}

The first extraction essence of $C$. bergamia was obtained by manual pressure of the peel of the fruit and absorbed by natural sponge placed on special cups, called "concoline"; the complete process that was described, by Domenico Sestini, in 1780, was carried on, often at night-time, by expert workmen, the "sfumatori" [13]. In 1844, with the invention of the "Calabrian Machine" by N. Barillà, the first real industrialization of the extraction process of the essence, took place that was able to assure, in short time, not only a high output but also an excellent quality of the essential oil. Nowadays, the natural essence is extracted from the peel by a cold-pressing procedure [14]. Later, in 1908, because of the dramatic earthquake that razed the Reggio Calabria town, the bergamot growing stopped suddenly; only, in the 1960, it reached the maximum economic expansion (4,000 hectares) but then, it slowly decreased, until the end of last century, due to the housing boom and the diffusion of synthetic essences [15]. Since the eighteenth century, this crop has been cultivated, almost exclusively, in the Calabria region, in the province of Reggio Calabria, in a narrow strip of land, about a hundred kilometers long, between Villa San Giovanni and Gioiosa Ionic towns, on a surface of 1.200 ha. This stretch of coast, is the exclusive productive area able to provide more of $90 \%$ of the world bergamot production with a crop of 250 $\mathrm{q} / \mathrm{ha}$, to produce $100.000 \mathrm{~kg}$ of essence. To obtain one kilogram of essence, about $200 \mathrm{~kg}$ of fruits are necessary [16]. The very exclusive microclimate of this small area, due to alluvial and argillaceous soils rich of mineral salts and geographical exposition, with rainy winters and warm-humid summers, favors the optimum development and production of the bergamot plant. This citrus is very sensitive to the thermal shock and the spring mists, and it is resistant to the breezes, because it needs to reduce the fungus infections. We can find that, also in some areas of Africa ( Costa d'Avorio, Mali, Cameroun, Guinea) and of South America (Argentina and Brazil), C. bergamia growing but the concentration of the compounds of its rind oil, is highly variable and therefore, unprofitable [17]. The collecting of suitable fruits for the essential oils extraction, is carried out from December to the end of February, by skilled workers [18]. Bergamot is a middle-sized plant; its productivity lasts up to 25 years. It generally, develops slower than other citrus species with regular and symmetrical foliage. The tree 
is moderately vigorous, at full maturity, it is medium-small to medium in size. The leaves are large and somewhat like the lemon in color, form and emargination, although the blades are sharper-pointed and the petioles are longer and more broadly winged. The flower buds and flowers are medium-large and pure white. The small to medium large lemon-yellow-colored fruits are hesperidium with an average weight of 150 gr. and usually, have a persistent style. They present an exocarp, an external part with a lot of utricles full of essential oil, a spongy monocarp and an endocarp. The rind is medium-thin with a smooth to moderately rough surface, commonly ridged and adherent. The segments are numerous and the core solid. The flesh is moderately firm, pale greenish-yellow, and highly acid with a faint bitter aftertaste. The highly monoembryonic seeds, comparatively few and sometimes none, often are not well developed. The cotyledons are white or faintly green. A distinctive characteristic of both foliage and fruits, is the strongly pungent and agreeably aromatic oil, which is similar to that of the sour orange leaf, though the rind oil of the latter is different. The flowering time is between the end of the March and the half of May while the harvesting comes from November to March [19]. There are currently three distinct cultivars of Citrus bergamia: "Femminello", "Castagnaro" and "Fantastico". The "Femminello" cultivar is a fast-growing plant that is not very developed with lanceolate leaves, spherical fruit and a thin exocarp rich in essential oils; it is the more aromatic, and it is therefore, preferred to the other cultivars. It is also, the earliest because the harvest begins in early October. The "Castagnaro" cultivar is a rustic plant, resistant to strong winds and long-lived, with large and lanceolate leaves and globular fruit with exocarp of medium thickness; it has an average content of essential oils. The harvest begins in November. The "Fantastico" cultivar is rustic and highly productive plant with very large leaves, globular, pear-shaped fruit and oil with an excellent aroma. Although it has been introduced more recently, it constitutes the largest percentage of fruit production. The harvest-time is between November and December [20].

\section{Bergamot Uses}

\subsection{Cosmetic Use}

The bergamot essence belongs to essential oils which are volatile, natural, limpid complex compounds characterized by a strong odor; they are produced by various aromatic plants, as secondary metabolite and usually, obtained by steam or hydro-distillation; each essential oil, is a very complex mixture of molecules which contains between 20 and 70 components, with low molecular weight and at different concentrations. Most molecules are present in traces while two to three, are often the most representative components, accounting for $20-70 \%$ of the whole oil and responsible for determining its biological activities [21]. There is a high variation in the chemical profile of essential oils depending on the extraction methods, organ used, age and vegetative stage of the plant, the time of the harvest and the soil composition $[22,23]$. Bergamot oil, is one of the most important perfume materials; its pleasant refreshing scent, blends into almost, any perfume composition so that, today, there is not a perfume which does not contains BEO (Bergamot Essential Oil). It imparts delicate top notes and at the same time, strength and body to the perfume. Phytochemical, essential oils, have been considered attractive, for their wide variety of bioactivities. About 3,000 essential oils, are known of which 300 are very important for pharmaceutical, cosmetic and perfume industries [24]. The bergamot essence is a clear yellow-green liquid, obtained by cold pressing of epicarp and partly, of the mesocarp, of the fresh fruit. It consists of a volatile (93-96\% of total) and a non volatile (4-7\% of total) fraction; the former contains monoterpene and sesquiterpene hydrocarbons such as limonene (40\%) and oxygenated derivatives such as linalool (8\%) and linalyl acetate 
(28\%). The hydrocarbon fraction does not have a fundamental role, in determining the olfactory character of the essence, but oxygenated compounds mark the flavor [25]. Monoterpenes are the most abundant constituents and often, the antitumor activity of the essential oil, has been related to their presence in the phytocomplex [26]. The non-volatile residue contains waxes and polymethoxylated flavones, coumarins and psoralens (bergapten (5-methoxypsoralen), bergamottin (5-geranyloxypsoralen)) which influence the olfactory properties of the essence. A large body of experimental data, accumulated during the last 20 years, have stressed that the psoralens, among other uses, are employed in therapy of psoriasis and vitiligo [27]. In addition, experimental evidence demonstrates that the phytocomplex may interfere with the receptor-mediated mechanisms of regulation of synaptic levels of amino acid neurotransmitters [28]. Then, the bergapten compound binding to DNA under ultraviolet A light exposure, produces compounds which are cytotoxic and highly mutagenic [29, 30]. So, bergamot essence was restricted or banned in many countries, because of certain adverse effects, due to photosensitive and melanogenic properties of bergapten; in fact, the bergapten-free extract of the essence are prepared by extractive industries for perfumery and cosmetic uses. In addition, recent experimental evidence, demonstrates that the bergamottin might be endowed with $\mathrm{Ca}++$ antagonist properties "in vitro" [31,32]. The nonvolatile fraction is a natural odor fixative, which influences the olfactory properties of the oil. However, the bergamot essence constitutes the base of cologne water (eau de cologne) and of the most widely perfumes, due to its ability to fix and amalgamate different fragrances, in the unique bouquet. It also, gives substance to soaps, tooth-pasts and deodorants and it is an important component of tanning creams, due to the presence of photodynamic compounds as fucomarins and terpens [33-37]. However, there are other types, of very valuable bergamot essence: the "petit grain" extracted from the leaves and tender branches, which are very useful to impact a strong refreshing note; the "bergamottella essence" from immature fruits and the "neroli", a highly esteemed, very expensive, extract that is obtained from the flowers.

\subsection{Medicinal Use}

The use of essential oils, as antimicrobial agents for topical treatment of infections, is well known in popular tradition. Recently, the potential antimicrobial effects of certain plant oil have attracted serious attention within the scientific community [38]. It has always attributed anti-infective properties to bergamot oil but its medicinal effects have received only limited attention [39, 40]. Its efficacy and safety have been validated, by means of consistent clinical and accurate testing [14]. Recent studies indicated that bergamot oil was active, in vitro, against several common species of dermatophytes, suggesting its potential use as antibacterial and antiseptic in gynecology and dermatology [41]. Also, in preservation of fresh fruit quality and safety, during postharvest cold storage, is recommended chitosan $(\mathrm{CH})$ coating with bergamot oil because of its highest antimicrobial activity [42].

Moreover, bergamot essence, as well as other essential oils, obtained from a range of aromatic plants, are used increasingly, in aromatherapy, a specialized form of phytotherapy [43]. It is highly diffused, in the industrialized countries, as an adjuvant treatment in cancer care, for the management of some symptoms of dementia, acute and chronic pain, depression and anxiety [44, 45]. This therapy is a natural way of healing a person's mind, body and soul. Many ancient civilizations, like Egypt, China and India, have used it as a popular complementary and alternative therapy from at least 6,000 years [46]. Aromatherapy that uses natural essential oils was found to be superior when compared to synthetic odors which generally contain irritants, like solvents and propellants causing irritation in some people [47]. Only recently, a 
growing of scientific studies investigated the neurobiological effects of the essential oil, enlightening on the cellular targets of the different active ingredients of the phytocomplex [48, 49]. Aroma components are therapeutically effective, for their psychological effects due to a direct action to cortical areas and their ability to cross blood brain barrier [50]. The penetration potential of the oil to reach the subcutaneous tissues is one of the important characters of this therapy. The mechanism of this action involves integration of essential oil into a biological signal of the receptor cells in the nose, when inhaled. The signal is transmitted to limbic and hypothalamus parts of the brain, via olfactory bulb. These signals cause brain to release neuron messengers like serotonin, endorphin and noradrenalin, to link our nervous and other body systems assuring a desired change and to provide a feeling of relief [46]. In fact, there is an increased trend to use this therapy in the treatment of sleep disorder [51, 52]. Finally, a recent study reported that exposure of human SH-SY5Y neuroblastoma cells to $0.02 \%$ and $0.03 \%$ bergamot essential oil significantly reduced cell viability inducing both necrotic and apoptotic cell death cytotoxicity [53]. Really, it is demonstrated that only, the combination of limonene and linalyl acetate of the fitocomplex, was able to induce cell death [54].

Also, the bergamot juice that is considered a waste of the essential oil production, contains a considerable amount and variety of compounds, flavonoid and flavonoid glycosides, having important health implications [55]. There is great interest, in the possibility that the antioxidant potential of plant-derived phenolic compounds, such as flavonoids, may have beneficial effect on the human health [56]. As everybody knows, these nutrients are important for limiting damaging oxidative reactions in the cells, which may predispose the development of major clinical conditions, such as heart disease and cancer. Recently, it is demonstrated that the flavonoid components of juice, naringin, neoriotricin and neohesperidin, reduce "in vitro" the carcinogenic cells growth in the human neuroblastoma and its metastasis [57, 58]. Moreover, rare higher molecular weight flavonoids which play a well known role, in the local folk medicine, in anticholesterolemic activity, are also found in bergamot fruit albedo [59]. These compounds which are flavonoid diglycosides, and called HMG-flavonoids carrying the 3-hydroxy-3-methylglutaric acid (HMG) moiety, are brutieridin and melitidin. They are absent in other citrus species (only a very few amounts in $C$. myrtifolia Raf.) and posses statin-like activity. In fact, they inhibit the production of cholesterol in blood thus determining the triglycerides and carbohydrates level and providing beneficial effects also, in the fight against hepatic steatosis and diabetes $[60,61]$.

\subsection{Other Uses}

The bergamot fruit juice is also used as flavouring, in gastronomy and the confectionery industry, for the preparation of fresh and dry pastries, sweets, candied peel, ice-cream and sorbets, as well as in soft drinks, cocktails and liqueurs (the well-known 'Bergamino', typical product of Reggio Calabria town, is exported to all over the world) $[62,63]$. Moreover, this juice that has not reached the popularity of other citrus juices, in the daily diet, for its organoleptic properties, is used in industrial preparations, to fortify fruit juice in place of synthetic additives [59, 64]. In addition, another bergamot product, the "pastazzo", which is constituted by pulp and peel of the fruits, and obtained after the extraction process of the essence, is a good soil improver [65, 66]. It is also used, either fresh or dried, as energy and desirability source in daily ration of animal feed [67, 68]. Finally, the dry peel of bergamot fruits is utilized to make some snuff-boxes and original souvenirs [69].

\section{Conclusion}

Above all, the bergamot fruit is cultivated for its essential oil, and it is a product that is in great demand, 
in the perfumery and cosmetic industries. The European Union has recognized the bergamot essence of Reggio Calabria, as a product of DOP (Protected Denomination of Origin). Many legislative efforts have been done to protect this geographical brand that it is not the arrival point of the effective marketing politics but it represents the foundation for the development and exploitation of organized and stable production. So the Calabrian Regional Board has delegated the "Bergamot Consortium" to guarantee both the purity of the essence and its continuous availability. In fact, as a widely used and highly competitive article, bergamot oil is frequently, adultered. Because of the great variety of natural isolates and terpenes, from the other citrus oils, it is relatively simple to sophisticate bergamot oil in such a way that moderate additions of these products, cannot be detected in the course of routine analysis. Moreover, the abundance of nutraceutical compounds which are present in the juice and pulp of the bergamot have attracted serious attention, within the scientific community. Actually, there is great interest, in the antioxidant potential of plant-derived phenolic compounds because of their beneficial effects, on human health. Recent studies have found that, although bergamot essential oil have been used, for centuries reputedly effectively as a traditional medicine, there is very little verified scientific evidence to support this use Particularly, the pharmacology of essential oil and/or their single chemical constituents remains largely to be discovered. To conclude, the data reported herein, emphasize the therapeutic and dietetic potential of the bergamot fruit that appears to be of great importance for the human health. And further studies are needed to better define the medicinal effects of its phytocomplex, that have received, only limited attention, also if the essential oils have been used in traditional medicine since ancient time. So, the bergamot growing is an important pillar of positive economic reality of Calabria region. It needs safeguarding because the research on its biological activities is still in its growing state and a systematic and rigorous approach to the study of potential phytotherapeutics was an achievement in the last decades.

\section{References}

[1] Webber, H. J. 1967. "History and Development of the Citrus Industry." In The Citrus Industry, University of California Press, Berkeley 1: 1-39.

[2] Calabrese, F. 1992. "The History of Citrus in the Mediterranean Countries and Europe." In Proc. Int. Soc. Citricult 1: 35-8

[3] Spiegel-Roy, P., and Goldschmidt, E. E. 1996. Biology of Citrus. Cambridge: University Press.

[4] Wu, G. A., and Rokhsar, D. 2014. "Sequencing of Diverse Mandarin, Pummel and Orange Genomes Reveals Complex History of Admixture during Citrus Domestication." Nature Biotechnology 32 (7): 656-62.

[5] Scora, R. W. 1988. "Biochemistry, Taxonomy and Evolution of Modern Cultivated Citrus." In Proceedings of the International Society of Citriculture, 277-89.

[6] Chapot, H. 1962. Le Bergamotier. Institut National de la Recherche Agronomique 5: 1-27.

[7] Nicolosi, E., Deng, Z. N., Gentile, A., La Malfa, S., Continella, G., and Tribulato, E. 2000. "Citrus Phylogeny and Genetic Origin of Important Species as Investigated by Molecular Markers." Theor Appl Genet 100 (8): 1155-66.

[8] Li, X., Xie, R., Lu, Z., and Zhou, Z. 2010. "The Origin of Cultivated Citrus as Inferred from Internal Transcribed Spacer and Chloroplast DNA Sequence and Amplified Fragment length Polymorphism Fingerprints." J. Amer. Soc. Hort. Sci. 135 (4): 341-50.

[9] Di Giacomo, A., and Mangiola, C. 1989. "Il Bergamotto di Reggio Calabria." Laruffa Editore, Reggio Calabria.

[10] Pellegrino, P., Mafrica, R., and Zappia, R. 2015. "La Coltivazione del Bergamotto tra Tradizione ed Innovazione." Proceedings of the Congress "Storie di Bergamotto." Artemis ed., Reggio Calabria, Italy. 33-50.

[11] Amato, P. 2005. "Storia del Bergamotto di Reggio Calabria." Città del Sole Edizioni, Reggio Calabria, Italy.

[12] Agosteo, G. E. 2015. "Il Bergamotto di Reggio Calabria: le Ragioni di un Monopolio Naturale." Proceedings of the Congress "Storie di Bergamotto" Artemis ed., Reggio Calabria, Italy. 51-64.

[13] Crispo, F., and Dugo, G. 1998. "Il Bergamotto: Coltivazione, Tecnologie di Estrazione, Aspetti Storici e Legislativi." Proceedings of the Internationa Congress "Bergamotto 98-Stato dell'arte e prospettive" Laruffa ed., Reggio Calabria, Italy. 163-78. 
[14] Romano, L., Battaglia, F., Masucci, L., Posteraro, B., Plotti, G., Zanetti, S., et al. 2005. "In Vitro Activity of Bergamot Natural Essence and Furocoumarin-Free and Distilled Extracts and their Associations with Boric Acid, against Clinical Yeast Isolates.” Journal of Antimicrobal Chemotherapy 55 (1): 110-4.

[15] Bellia, F. 1979 "Indagine Economica-Agraria Sulla Bergamotti Coltura." Progetto Speciale 11 Sviluppo dell'agrumicoltura Cassa per il Mezzogiorno, Roma, Italy.

[16] Falcone, G., Stillitano, T., De Luca, A. I., Nicolò, B. F., Franco, F., and Gulisano, G. 2015. "La Sostenibiltà Ambientale ed Economica Della Coltura Della Coltura del Bergamotto." Proceedings of the Congress "Storie di Bergamotto", Artemis ed., Reggio Calabria, Italy. 197-202.

[17] Nesci, F. S., Sapone, N., and Baldari, M. 2011. "Tutela e Sviluppo del Bergamotto Reggino." Proceedings of the XXXII Annual Scientific Conference AISR "Il Ruolo Delle Città Nella Economia Della Conoscenza" Turin, Italy.

[18] Sicari, V., Poiana, M., and Mincione, A. 2015. "Tecnologie di Trasformazione del Bergamotto." Proceedings of the Congress "Storie di Bergamotto" 153-65 Artemis ed., Reggio Calabria, Italy.

[19] Hodgson, R. W. 1967. "History, World Distribution, Botany and Varietes." In The Citrus History, Reuter \& Batchelor Ed., University of California, Berkeley 1: 494-6.

[20] De Domenico, C., Cotroneo, A., Troizzi, A., and Rapisarda, A. 2004. "Ultrastructural Analysis of the Secretory Tissues during Ontogenesis of Citrus Bergamia Risso \& Poiteau Fruit." In Proceedings of the 35th International Symposium on Essential Oils, Giardini Naxos, Messina, Italy.

[21] Bakkali, F., Averbeck, S., Averbeck, D., and Idaomar, M. 2008. "Biological Effects of Essential Oils: a Review." Food and Chemical Toxicology 46 (2): 446-75.

[22] Angioni, A., Barra, A., Coroneo, V., Dessi, S., and Cabras, P. 2006. "Chemical Composition, Seasonal Variability and Antifungal Activity of Lavandula Stoechas L. Sspstoechas Essential Oils from Stem/Leaves and Flowers." Journal of Agricultural and Food Chemistry 54 (12): 4364-270.

[23] Masotti, V., Juteau, J., Bessiere, M., and Viano, J. 2003. "Seasonal and Phenological of the Essential Oil from the Narrow Endemic Species Artemisia Molinieri L. and its Biological Activities." Journal of Agricultural and Food Chemistry 51 (24): 7115-21.

[24] Russo, R., Corasaniti, M. T., Bagetta, G., and Morrone, L. A. 2015. "Exploitation of Cytotoxicity of Some Essential Oils for Translation in Cancer Therapy." Hindawi
Publishing Corporation.

[25] Sakurada, T., Kuwahata, H., Katsuyama, S., Komatsu, T., Morrone, L. A., Corasaniti, M. T., et al. 2009. "Intraplantar Injection of Bergamot Essential Oil into the Mouse Hindpaw: Effects on Capsaicin-Induced Nociceptive Behaviors". International Review of Neurobiology 85: 237-48.

[26] Sobral, M. V., Xavier, A. L., Lime, T. C., and de Sousa, D. P. 2014. "Antitumor Activity of Monoterpenes Found in Essential Oils." The Scientific World Journal 23.

[27] Bagetta, G., Morrone, L. A., and Rombolà, L. 2010. "Neuropharmacology of the Essential oil of Bergamot." Fitoterapia 81 (6): 453-61.

[28] Morrone, L. A., Rombolà, L., Pelle, C., Corasanit, M. T., Zappettini, S., Paudice, P., et al. 2007. "The Essential Oil of Bergamot Enhances the Levels of Amino Acid Neurotransmitters in the Hippocampus of Rat: Implication of Monoterpene Hydrocarbon." Pharmacologiocal Research 55 (4): 255-62.

[29] Ashwood-Smith, M. J., Poulton, G. A., and Mildenberger, M. 1980. "Methoxypsoralen, an Ingredient in Several Suntan Preparations, has Lethal, Mutagenic and Clastogenic Properties.” Nature 285 (5764): 407-9.

[30] Zaynoun, S. T., Johnson, B. E., and Frain-Bell, W. 1977. "A Study of Oil of Bergamot and its Importance as a Photoxic Agent. Characterization and Quantification of the Photoactive Component." J. Dermatol 96: 475-82.

[31] Occhiuto, F., and Circosta, C. 1996. "Antianginal and Antiarrhythmic Effects of Bergamottin, a Furocoumarine Isolated from Bergamot Oil." Phytother Res. 10 (6): 491-6.

[32] Occhiuto, F., and Circosta, C. 1997. "Investigation to Characterize Antiarrhythmic Action of Bergamottin, a Furocoumarine Isolated from Bergamot Oil." Phytother Res 11: 450-3.

[33] Forlot, P. 1998. “Cosmesi e usi Cosmetici Dell'essenza di Bergamotto." In Proceedings of the International Congress: "Bergamotto 98. Stato dell'arte" Laruffa ed., Reggio Calabria, Italy. 45-52.

[34] Freeman, L. 1989. "A Dose Response Study of a Sunscreen Product with Bergapten.” In Fitzpatrick, T. B., Forlot, P., Pathak, M. A., Urbach, E., Psoralen: Past, Present and Future of Photochemoprotection and other Biological Activities. Eds. John Libbey Eurotext-London-Paris.

[35] Kligman, A. M., and Forlot, P. 1992. "Photoprotection Compare du Bronzage Induit chez L'Homme par un Rayonnement Solaire Simulè et avec Application d'un Produit Solaire Contenant du Bergaptene." Nouv. Dermatol 11: 666-73.

[36] Levine, N. 1989. "The Effect of Bergaptene and Sunlight on Cutaneos Pigmentation.” Arch. Dermatol 125 (9): 
1225-30.

[37] Zaynoun, S. T. 1977. "A Study of Oil Bergamot and its Importance as a Phototoxic Agent. The Factor which Affect the Photoxic Reaction Induced by Bergamot Oil and Psoralen Derivatives." Contact Dermatitis 3: 225-39.

[38] Dorman, H. J., and Deans, S. G. 2000. "Antimicrobial Agents from Plants: Antibacterial Activity of Plant Volatile Oils." Journal of Applied Microbiology 88 (2): 308-16.

[39] Focà, A., Liberto, M. C., Barreca, G. S., Pollio, A., and Caliò, A. 1998. "Valutazione dell'attività antimicrobica dell'essenza del bergamotto." In Proceedings of the International Congress: "Bergamotto 98. Stato dell'arte" Laruffa Ed., Reggio Calabria, Italy. 185-207.

[40] Pizzimenti, F., Tulino, G., and Marino, A. 1998. "Antimicrobial and Antifungal Activity of Bergamot Oil." In Proceedings of the International Congress: "Bergamotto98. Stato dell'arte" Laruffa Ed., Reggio Calabria, Italy. 181.

[41] Sanguinetti, M., Posteraro, B., Romano, L., Battaglia, F., Lopizzo, T., De Carolis, E., et al. 2007. "In vitro Activity of Citrus Bergamia (Bergamot) Oil against Clinical Isolates of Dermatophytes." Journal of Antimicrobial Chemotherapy 59 (2): 305-8.

[42] Gonzalez, L., Pastor, C., Vargas, M., Chiralt, A., Gonzalez-Martinez, C., and Chafer, M. 2011. "Effect of Hydroxypropylmethyl Cellulose and Chitosan and Chitosan Coatings with and without Bergamot Essential Oil on Quality and Safety of Cold-Stored Grapes." Postharvest Biology and Technology 60 (1): 57-63.

[43] Halcon, L. L. 2002. "Aromatherapy: Therapeutic Applications of Plant Essential Oils." Minnesota Med. 85 (1): 42-6.

[44] Perry, N., and Perry, E. 2006. "Aromatherapy in the Managment of Psychiatric Disorders: Clinical and Neuropharmacological Perspectives." CNS Drugs 20 (4): 257-80.

[45] Barocelli, E., Calcina, F., Chiavarini, M., Impicciatore, M., Bruni, R., Bianchi, A., et al. 2004. "Antinociceptive and Gastro Protective Effects of Invade and Orally Administered Lavandula Hybrida Reverchon "Grosso" Essential Oil." Life Sci. 76: 213-23.

[46] Ali, B., Al-Wabel, N., Shams, S., Ahamad, A., Khan, S., and Anwar, F. 2015. "Essential Oil Used in Aromatherapy: A Systemic Review." Asian. Pac. J. Trop Biomed 5 (8): 601-11.

[47] Celeiro, M., Guerra, E., Lamas, J. P., Lores, M., Garcia-Jares, C., and Lompart, M. 2014. "Development of a Multianalyte Method Based on Micro-Matrix-Solid-Phase Dispersion for the Analysis of Fragrance Allergens and Preservatives in Personal Care Products." J. Chromatogr. A: 1344: 1-14.
[48] Rombolà, L., Corasaniti, M. T., Rotiroti, D., Tassorelli, C., Sakurada, S., Bagetta, et al. 2009. "Effects of System Administration of the Essential Oil of Bergamot (BEO) on Gross Behavior and EEG Power Spectra Recorded from the Rat Hippocampus and Cerebral Cortex." Functional Neurology 24 (2): 107-12.

[49] Rombolà, L., Amantea, D., Russo, R., Adornetto, A., Berliocchi, L., Tridico, L., et al. 2016. "Rational Basis for the Use of Bergamot Essential Oil in Complementary Medicine to Treat Chronic Pain." Medicinal Chemistry 16 (9): 1-8.

[50] Villemure, C., and Bushnell, M. C. 2007. "The Effects of the Steroid Androstadienone and Pleasant Odorants on the Mood and Pain Perception of Men and Women." Eur. J. Pain 11 (2): 181-91.

[51] Marchad, L. 2014. "Integrative and Complementary Therapies for Patients with Advanced Cancer." Ann Palliat Med. 3 (3): 160-71.

[52] Hwang, E., and Shin, S. 2015. "The Effects of Aromatherapy on Sleep Improvement: a Systematic Literature Review and Meta-Analysis." J. Altern Complement Med. 21 (2): 61-8.

[53] Mondello, L., Dugo, P., Bartle, K. D., Dugo, G., and Cotroneo, A. 1995. "Automated HPLC-HRGC: a Powerful Method for Essential Oils Analysis. Part. V. Identification of Terpene Hydrocarbons of Bergamot, Lemon, Mandarin, Sweet Orange, Bitter Orange, Grapefruit, Clementine and Mexican Lime Oils by Coupled HPLC-HRGCMS (ITD)." Flav Fragr J. 10: $33-42$.

[54] Verzera, A., Trozzi, A., Gazea, F., Cicciarello, G., and Cotroneo, A. 2003. "Effect of Rootstock on the Composition of Bergamot (Citrus bergamia Risso et Poiteau) Essential Oil.” J. Agric. Food Chem. 51 (1): 206-10.

[55] Russo, R., Ciociaro, A., Berliocchi, L., Cassiano, M. G. V., Rombola, L., Ragusa, S., et al. 2013. "Implication of Limonene and Linalyl Acetate in Cytotoxicity Induced by Bergamot Essential Oil in Human Neroblastoma Cells." Fitoterapia 89 (1): 48-57.

[56] Conidi, C., Cassano, A., and Drioli, E. 2011. "A Membrane-Based Study for the Recovery of Polyphenols from Bergamot Juice." Journal of Membrane Science 375 (1-2): 182-90.

[57] Garry, D., and Crozier, L. 2000. "Plant-Derived Phenolic Antioxidants." Current Opinion in Lipidology 11 (1): 43-7.

[58] Delle Monache, S., Sanità, P., Trapasso, E., Ursino, M. R., Dugo, P., Russo, M., et al. 2013. "Mechanisms Underlying the Anti-Tumoral Effects of Citrus Bergamia Juice." PLoS One 8 (4): e61484.

[59] Navarra, M., Ursino, M. R., Farlazzo, N., Russo, M., 

the Exclusive Essence of Calabria: A Review

Schumacher, U., and Valentiner, U. 2014. "Effect of Citrus Bergamia Juice on Human Neuroblastoma Cells in vitro and in Metastatic Xenograft Models." Fitoterapia 95: 83-92.

[60] Di Donna, L., De Luca, G., Cazzati, F., Napoli, A., Salerno, R., Taverna, D., et al. 2009. "Statin-Like Principles of Bergamot Fruit (Citrus Bergamia): Isolation of 3-Hydroxymethylglutaryl Flavonoid Glycosides." Nat. Prod. 72 (7): 1352-4.

[61] Di Donna, L., Gallucci, G., Malaj, N., Romano, E., Tagarelli, A., and Sindona, G. 2011. "Recycling of Industrial Essential Oil Waste: Brutieridin and Melitidin, two Anticholesterolaemic Active Principles from Bergamot Albedo." Food Chemistry 125 (2): 438-41.

[62] Montemurro, V. 2015. "Il Bergamotto: Bene Prezioso a Tutela Della Salute.” Artemis Ed., Reggio Calabria.

[63] Spinelli, R. 1998. "Il Bergamotto nella Gastronomia." In Proceedings of the International Congress: "Bergamotto 98. Stato dell'arte" Laruffa Ed., Reggio Calabria, Italy. 233-8.

[64] Spinelli, R., and Sandicchi, M. 2000. "Il Bergamotto ed Altri Agrumi in Gastronomia." Laruffa Ed. Reggio Calabria, Italy.
[65] Cautela, D., Laratta, B., Santelli, F., Trifirò, A., Servillo, L., and Castaldo, D. 2008. "Estimating Bergamot Juice Adulteration of Lemon Juice by High-Performance Liquid Chromatography (HPLC) Analysis of Flavanone Glycosides." Journal of Agricultural and Food Chemistry 56: 5407-14.

[66] Foti, F. 2015. "Utilizzazione Zootecnica del Pastazzo Fresco di Bergamotto." Proceedings of Congress "Storie di bergamotto" Artemis Ed., Reggio Calabria, Italy. 177-186.

[67] Crispo, F. 2014. "Bergamot in the Calabrian Economy and the Role of Consorzio del Bergamotto." In Citrus bergamia (Bergamot) and Its Derivatives. Dugo, G. \& Bonnaccorsi (Eds.). CRC Press, Taylor \& Francis Group.

[68] Bognanno, M. 2015. "Utilizzazione Zootecnica del Pastazzo ed Essiccato di Bergamotto." Proceedings of the Congress "Storie di Bergamotto", Artemis Ed., Reggio Calabria, Italy.

[69] AA.VV. 2000. "Colori e Sapori di Calabria." ARSSA.

[70] Hammer, K., Knupffer, H., Laghetti, G., Perrino, P. 1992 "Seeds from the past. A catalogue of crop germplasm in south Italy and Sicily". Istituto del Germoplasma (C.N.R.), Bari. 